al-Ihkam: Jurnal Hukum dan Pranata Sosial, 16 (1), 2021: 68-86

ISSN: 1907-591X, E-ISSN: 2442-3084

DOI: http://doi.org/10.19105/al-lhkam.v16i1.4517

\title{
Tarjih Maqashidi of Granting Remission for Terrorist Convict in Indonesia
}

\author{
Dwi Aprilianto \\ Universitas Islam Lamongan (UNISLA), Jl Veteran No 53 Lamongan \\ Email: dwiaprilianto4324@gmail.com \\ Salman Zahidi \\ Universitas Islam Lamongan (UNISLA, Jl Veteran No 53 Lamongan \\ Email: salmanzahidi04@gmail.com
}

Article history: Received: 20 September 2020, Accepted: 11 February 2021, Published:

27 June 2021

\begin{abstract}
:
The problem of the deradicalization policy of terrorist convicts is in the regulation of granting remissions for terrorism convicts because terrorist convicts can manipulate the conditions for granting remission to pretend to be good and cooperative (taqiyah) during their criminal period in prison, so that they can quickly gain freedom and return to the network. This empirical research was processed descriptively. Data collection was carried out through field research at the Class I Lapas Surabaya prison and Class II B Lamongan prison through a phenomenological approach, interpretive paradigm, and tarjih maqashidiy analysis. This study concludes that granting remissions to terrorism convicts has a more significant advantage (maslahah) than eliminating remissions on the grounds of extraordinary crimes. Providing the opportunity to change behavior is better prioritized than providing punishment without any attempt to change the behavior of terrorist prisoners with the maximum penalty.
\end{abstract}

\section{Keywords:}

Tarjih Maqashidi; Remission; Terrorist Convicts

\begin{abstract}
Abstrak:
Author correspondence email: $\underline{\text { dwiaprilianto4324@gmail.com }}$ Available online at: http://ejournal.iainmadura.ac.id/index.php/alihkam/ Copyright (c) 2021 by al-ihkam. All Right Reserved


Salah satu problematika yang muncul dari kebijakan deradikalisasi narapidana terorisme adalah aturan perihal pemberian remisi bagi narapidana terorisme dengan syarat kelakuan baik dan kooperatif (taqiyah) selama menjalani masa pidana. Padahal, mereka bisa berpur-pura baik agar segera keluar dari penjara dan kembali ke jaringan lamanya. Penelitian empiris ini diolah secara deskriptif sementara pengumpulan datanya dilakukan melalui observasi dan wawancara di Lapas Kelas I Surabaya dan Kelas II B Lamongan dengan pendekatan fenomenologi, paradigma interpretif, dan analisis tarjih maqashidi. Studi ini menyimpulkan bahwa pemberian remisi pada narapidana terorisme memberikan keuntungan yang lebih signifikan (maslahah) dibanding menghapus kebijakan tersebut dengan alasan kejahatan luar biasa yang dilakukan narapidana. Memberikan kesempatan mereka untuk berubah lebih baik dianggap lebih utama dan layak diprioritaskan dibanding memberi hukuman maksimal tanpa usaha apapun untuk mengubah perilakunya.

\section{Kata Kunci:}

Tarjih maqashidi; Remisi; Narapidana Terorisme

\section{Introduction}

The deradicalization policy of terrorism convicts in Indonesia is contained in the rules of granting remission. It becomes problematic because the convicts can simply manipulate the conditions by pretending to behave well and cooperatively (taqiyah) during their criminal period in the prison. Therefore, they can quickly get released and return to the old network.

Some facts of recidivism on former terrorism convicts show how they were re-involved in the terrorist network after being released from Class I Prison Surabaya. They are Nasruddin Mukhtar Moh Sholah Ikhwan, Suryadi Masud, and Syarief Tarabubun who respectively could quickly get lenient sentencing then returning to the old terrorism network. ${ }^{1}$

In general, deradicalization can be successful only in terrorism convicts under the category of terrorism sympathizers instead of

\footnotetext{
${ }^{1}$ Documentation Class I Lapas Surabaya prison and Class II B Lamongan prison.
} 
members of executioners/ideologists. This is mainly because the later group plays an essential role in planning or spreading the violent ideology.

Another problem of remission rules for terrorism convicts is found in the Government Regulation No. 99 of 2012 concerning The Terms and Procedures for the Implementation of Correctional Inmates' Rights. This regulation is considered discriminatory against convicts because of ignoring their fundamental rights such as the right to obtain remission or reduce the punishment. For instance, Class I Surabaya prison terrorism convicts with life sentences (Fathurahman, Asep Djaja, and Ismail Yamsehu) who have met the requirements and been committed to the The Repulic of Indonesia still failed to get remission because their verdicts have not been reviewed yet.

The fact that many radical terrorism convicts still refuse to participate in deradicalization program in the prison is partly due the terrorism law which does not regulate the obligation for them to follow the program. The Law No. 5 of 2018 on the deradicalization of terrorism crimes does not even explicitly oblige them to follow the program.

In fact, terrorism as an extraordinary crime should also be distinctive in its punishment from other ordinary crimes. Accordingly, it makes sense to find policy suggestion on the different treatment of granting remission process for terrorism convicts.

In this context, some suggest that remission is contrary to the certainty of a fair law for crime victims. The verdict of a judge is supposed to represent a sense of community justice, but the government still possibly reduces its implementation without going through a retrial. Therefore, removing the procedure of remission cannot be categorized as human rights violation. Moreover, the basic philosophy and historical root of remission are the mercy of a Dutch queen. $^{2}$

On the other hand, pro-remission party argues that abolishing the chance of remission among terrorism convicts means violating their human rights. According to them, remission aims to prevent any further crimes and fix the characters of perpetrators. Therefore, no

2 Widja Priyatno, Sistem Pelaksanaan Pidana Penjara di Indonesia (Bandung: Refika Aditama, 2009). 
matter case of the convicts is, they are supposed to be entitled to remission as long as they behave well in serving their sentences. ${ }^{3}$

\section{Philosophy of Remission of Terrorism Convicts}

The implementation of prison sentences with the correctional system in Indonesia currently refers to Law No. 12 of 1995 on Correctional Services. Philosophically, the implementation is emphasized to the concept of rehabilitation and social reintegration so that inmates and juvenile offenders could realize their mistakes and return to be good citizens. This concept does not distinguish any form of crime, including at the process and the procedure of granting the remission and parole.

Based on the Government Regulation of the Republic of Indonesia Number 32 of 1999, remission is a reduction in the period of criminal life given to inmates and juvenile offenders who meet the conditions specified in the legislation. Meanwhile, the provisions of Article 1 of presidential decree of the Republic of Indonesia No.174 of 1999 does not give any clear definition of remission. It only reads: "Every inmate and juvenile offenders serving a temporary prison sentence and criminal confinement can be granted remission if they behave well during the criminal justice process."4

One of the conditions for terrorism convicts to get remission is to become so called justice collaborator by helping to dismantle the criminal case they committed. This is mainly crucial because their role in "uncovering" the veil of terrorism network crimes is difficult to do by any law enforcers. A justice collaborator is defined as a witness of a criminal case who is willing to help or cooperate with the law enforcers. Thus, the justice collaborator serves as both a witness and a suspect who must give the trial information. The information that he or she reveals will then be taken into consideration in obtaining remission. However, apart of this procedure, remission is proved not to be correlated with a decrease in the number of terrorism crimes. It

\footnotetext{
3 Government Regulation of the Republic of Indonesia Number 32 of 1999 concerning Terms and Procedures for the Implementation of the Rights of Correctional Assistants, Article 1 point 6.

4 Presidential Decree Number 174 of 1999 concerning Remissions, Article 1 number 1
} 
even tends to increase the number because some perpetrators repeat their offenses both inside and outside the prisons. 5

The policy of granting remission for terrorism convicts is therefore prone to be abused by the convicts and contrary to the certainty of a fair law for crime victims. The verdict that the judge has made to the terrorist convicts should have represented justice value that the public wishes. However, reducing the sentencing period without any trial is considered contrary to the value. The omission of remmision is therefore can't be considered as human right violation because remmision itself is based on mercy. The controversy over this remission stems from assumption that the verdict of the convicts is still very far from people's expectation considering terrorism as an extraordinary crime. ${ }^{6}$

Meanwhile, the philosophy of correctional sentence for terrorism convicts is essentially a temporary criminal deprivation of freedom for a specific duration of time instead of for lifetime with an indefinite period. On the other hand, a life sentence imposed on certain convicts has a particular purpose as a preresquite of rational criminal politics.

Relating to this, Bjorgo assumes that individuals actually do not want to commit any acts of terrorism. However, he/she can turn the life choice conversely once they join a radical group. Therefore, to omit and get rid of the radical ideology over a person and take him/her out of the radical group, it requires "pushing and pulling factors." The fromer is a negative factor that makes a person reluctant to remain in their old group, while the later is a positive factor in the form of an opportunity to live a more promising life. ${ }^{7}$

\footnotetext{
5 Government Regulation of the Republic of Indonesia Number 99 of 2012 concerning Second Amendment to Government Regulation Number 32 of 1999 concerning Terms and Procedures for the Implementation of Correctional Guidance Rights Article 43 A.

6 Roeslan Saleh and A. Josias Simons R, Budaya Penjara (Bandung: Karya Putra Darwati, 2010).

7 Naureen Chowdhury Fink and Ellie B. Hearne, Beyond Terrorism: Deradicalization and Disengagement from Violent Extremism (New York: International Peace Institute, 2008).
} 
Tarjih Maqashidi of Granting Remission

Table 2. 2 Pushing and Pulling Factor

Pushing Factor Pulling Factor

1. Social pressure and stigma that make them reluctant to remain in the radical groups.

2. Conflict or opposition in the group's internal circle.

3. Feeling disillusioned with the change in the leader's perspective or the condition

1. Attention from family or friends

2. Willingness to build a household.

3. Finding more interesting new ideology.

4. Willingness to improve economic conditions. when the leader is caught or killed.

4. Disappointed with the group's methods of violence act or loss of attention to group members.

5. Threats from the country or any inner circle of the group

6. Change of the group orientation.

7. Empathy for the victims.

\section{Tarjih Maqashidi}

Tarjih maqashidi is putting a certain law over others using the bonds (quyud) of maqashid shar'i (the main purpose of shariah). ${ }^{8}$ In another term, it is mentioned as taqdim (favoring one over another) when a mujtahid (those who do ijtihad or the search of law) prioritizes one of two contradictory proposition (dalil) due to the power (quwwah) of maslahah (advantages). ${ }^{9}$ Tarjih maqashidi or tarjh bi al-maqashid applies not only on the strong contradiction between two propositions, but also at the differences on the forms, kinds, and categories of maslahah and mafsadah (disadvantages) produced by the provision of law. ${ }^{10}$ In this article, we define tarjih maqashidi as the superiority of a law/policy based on its maslahah and mafsadah aspects

8 Muhammad Jabri Syamsuddin, Al-Tarjih al-Maqhasidi bayna al-Nusus alMuta'ariah, dalam http:/ /iefpedia.com/arab/?p=8130. accessed March 16, 2020.

9 Muhammad al-Asuri, "Al-Tarji@h\{ Bi Al-Maqas\}id Wa D\}awabituhu Wa Atsaruhu Fiqhi” (Universitas al-Haj Li Hadar Jazair, 2008). 38.

${ }^{10}$ Ahmad Imam Mawardi, Fiqh Minoritas (Yogyakarta: LKIS, 2010). 230. 
using theories of mizan maslahah (the scale of advantages) in the discipline of maqashid al-shari'ah.

Relating to this, Imam Nawawi said that doing tarjih to choose one of several opposing propositions is very important. In a broader scope, making a choice is a certainty in life that everyone can't avoid from. This tarjih process particularly enables intellectuals to achieve perfection in mastering various fields of science. 11

In tarjih practice, seeing the problem and contradiction in details will be a main way to understand the problem. Such conditions generally lead to a formulation of solution based on methods corresponding to existing contradictions to find more dominant maslahah situation (arjah masalih, more advantageous one). To assess and determine which one is more advantageous, a clear and consistent standard is required so that the dominant position exists definitively instead of assumption based.

When it is found contradiction between two types of maslahah or mafsadah, the categories of each will be observed whether it is daruriyah (primary), hajiyah (secondary), and tahsiniyah (tertiary). From this consideration, we bring up the five scales of maslahah and tarjih maqashidi concept of as follows:

1. Qimah Shumul al maslahah (the quality of maslahah);

2. Miqdar Shumul al maslahah (the quantity of maslahah);

3. Taakud Nataij al maslahah (the accuracy of maslahah);12

4. Quwah wa umum Atsar al maslahah (the effectiveness of maslahah); ${ }^{13}$

5. Imtidad Zama@ni al maslahah (the duration of maslahah). ${ }^{14}$

11 Jalal al-din 'Abd al-Rahman Ibn Abi Bakar al-Suyuti, Tadrib Al-Rawi Fi Sharh Taqrib Al-Nawawi, 2nd ed. (Beirut: Dar Ihya al-Sunnah al-Nabawiyyah, 1979).196.

12 Muhammad Sa'id Ramadan al-Buti, D fawabit Al-Maslahah Fi Al-Shariah AlIslamiyyah (Beirut: Mu'assasah al-Risalah, 2000). 249-254.

13 Abd Majid Najjar, Maqasłid Al-Shari'ah Bi Ab'ad Jadidah (Beirut: Dar Garib alIslami, 2008). 252-265.

14 Ahmad Al-Raysuni, Nazhariyyat Al-Taqrib aa Al-Taghlib F@ Al-Ulum AlIslamiyyah (Kairo: Dar al-Kalimah, 1997). 350-368. 


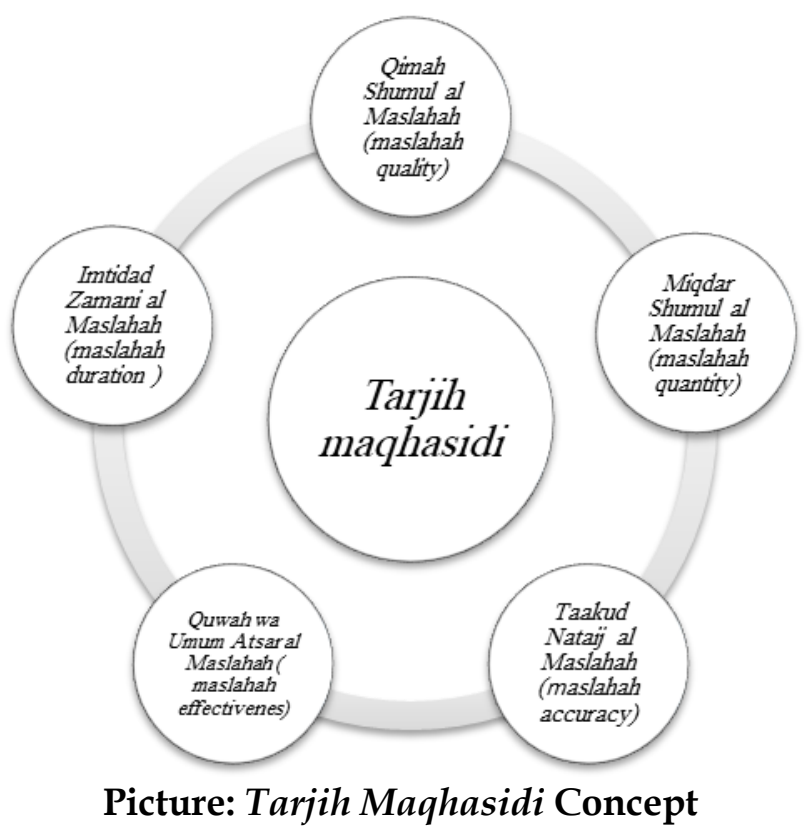

\section{Controversy on Terrorism Convicts Remission}

The lifetime sentences for Poso terrorists in Class I Prison Surabaya (Asep Jaja, Ismail Yamsehu and Fathurahman) shows contradiction among uncertain period of sentencing time, system of remission justice and correctional philosophy. Based on the Article 9 of the Republic of Indonesia Number 174 of 1999, a convict with a lifetime sentence has no hope for getting a remission before granting Presidential Clemency.

The positive law governing the granting of remissions to criminal convicts itself has reflected and applied the concept of disciplinary in a big framework of criminalization and nurturing the inmates. Moreover, remissions are typically not immediately granted to any inmates. There are stages or processes and conditions of remission that every inmate needs to fulfill. Such circumstances indicate that remission is a form of appreciation or "reward" for the inmate's good behavior.

The remission policy, particularly for terrorism convicts, raises controversy. Arguing between human rights in the framework of nurturing program and the deterrent effect for both convicts and people at general is a part of the controversy. Remission is 
furthermore partly seen as the right of terrorism convicts and in line with the philosophy of criminal implementation that enables them to socialize again with other people like before. If a convict has fulfilled the legislation's requirements, he or she must obtain the legislation's rights without exception, including terrorism convicts, as conveyed by Bambang Sugianto as follows:

"A strong reason on why terrorism convicts in class I Surabaya prison, including Umar Patek, wants to get remission is that because they want to go back to their families, wives and children. Included is those with lifetime sentence who hope to get clemency due to their excellent behavior in the prison. They wish that their proposal for a sentence review can be approved and the prison period can be shorthened to 20 years." 15

On the other hand, others assume that granting remissions for terrorism convicts is a form of denial on the community's sense of justice. The length of sentencing period imposed by the court and carried out by the convicts is still considered disproportionate to the losses due to terrorism that Indonesian people endure.

Apart of the controversy, a policy of criminal law on granting remission to terrorism convicts has been formulated specifically and differently from other crimes' convicts through the Government Regulation No. 28 of 2006 junto Government Regulation No. 32 of 1999. It regulates that terrorism convicts can get remission after serving a third of their sentence providing that they behave appropriately. This provision exists as a form of embodiment of a sense of justice in the law enforcement.

However, some legal practitioners still question the existence of injustice issue in granting remissions for terrorism convicts. They even propose a policy to abolish remission procedure claiming that the proposal is not contrary to human rights. Moreover, it is based on a firm legal foundation under both sociological and juridical reasons,

15 Bambang Sugianto, Interview, Sidoarjo 16 July 2019. 
namely fulfilling the formulation of community justice."16 On the contrary, some human rights activists assume that the policy not to grant any remission to terrorism convicts has been contrary to the concept of disciplinary itself. In other words, they assume that abolishing remission procedure seems to restore the criminal system in Indonesia into the older one in prison system.

In a short word, proposal of refusing grant remission for terrorism convicts deserves for an appreciation due to the spirit of terrorism eradication. Terrorism as an extraordinary crime had killed an incredible number of victims so that granting remission for its convicts is considered to hurt the community's sense of justice. The community demands that terrorist be punished severely following their actions. Furthermore, granting remission is deemed to be contrary to the spirit of the government in the eradication of terrorism crimes. However, in terms of the philosophy of law and the legal basis of its enforcement, it needs serious review to ensure that the policy has a firm regular basis and in line with the sentencing philosophy in the concept of correctional period. Regarding with that, Umar Patek said so:

\begin{abstract}
"Granting remission is very important for terrorism convicts, let alone those of us who have behaved well, positively, obeyed all the rules in prison, tried to help the government in deradicalization activities, and pledged to the Unity of Republic of Indonesia. Therefore, the government should give a clear reward and punishment to the inmates as a form of justice. However, the discourse of taqiyah by willingness to participate in deradicalization programs along with other wishes, according to me, is not equal with their ideology. The ideology can't be exchanged for a petty change called remission." 17
\end{abstract}

17 Umar Patek, Interview, Sidoarjo, 12 October 2019. 
Given this kind of situation, efforts to succeed the radicalization program among terrorist convicts as well as to deal with over capacity at the prison can be done by regulating very severe conditions for terrorist convicts to get remission. This strict requirement is deemed not to hurt the sense of justice among Indonesian people who put their hope to eradicate terrorism more effectively. Regarding with the controversy of remission, Mr. Sukir, the chief of guidance and correctional division of the Ministry of Law and Human Rights (Kemenkumham) East Java Office, explained as follow:

\begin{abstract}
"Along with public's demand which expects terrorism convicts to be punished severely, we just can do nothing when some of them remain at the old ideology by not joining any deradicalization program and not participating in nurturing activities of the correctional institution such as praying in the mosque or attending state ceremonies. Neither do they expect remission or conditional release. When this happens and the sentence period ends, we just release them and not hold them on even one more night. After the realease, it becomes the responsibility of The National Counter-Terrorism Agency (BNPT; Badan Nasional Penanggulangan Terorisme)." 18
\end{abstract}

In line with Sukir, Bambang Sugianto, a guardian (pamong) of terrorism convicts in Class I Surabaya prison explained the problem of remission for terrorism convict as follows:

"Controversy on the remission for terrorism inmates has long been rolling along with the change of policies. For instance, terrorism convicts are required to fulfill very heavy requirement ranging from participating in deradicalization

18 Sukir, Guidance correctional district Minister of Law and Human Rights (Menkumham) East Java, interview, Surabaya, 31 January 2019. 
programs, being justice collaborators by dismantling their old network, to willingness to pledge to the Unity of Republic of Indonesia under digital recording. Those requirements are not easy for them and when they are not really sincere or taqiyah, we can not know it for sure. However, the pledge will make them deemed as infidels by their old inner circle. Umar Patek knew and felt the contingency with claims and the term kafir addressed to him by other inmates." 19

\section{Tarjih Maqhasidi Application on the Remission for Terrorism Convicts}

Along with the controversy, it is worth to formulate suitable policy solution using the analysis of tarjih maqhasidi or scales maslahah as follows:

\section{The Quality of Maslahah}

One of purposes of granting remission is to reduce the negative impact on the freedom deprivation of inmates who behave well during the sentencing period while giving them confidence to be better persons. ${ }^{20}$ Therefore, the policy applies following the sentencing principles through correctional system and respects on inmates' human rights. The remission policy furthermore aims to provide pleasure and drive the inmates to maintain their attitude and behavior while in prison.

Remission is given in the hope that the inmates will be willing to repent and admit the wrongdoing. Furthermore, they are given a chance to return to their family and community. This is included in the protection of life (hifdz al-nafs) and human rights (hifdz al-huquq alinsan) in the dharuriyat category. It is mainly because the family left behind is in desperate need of the figure of the inmates, who typically

\footnotetext{
${ }^{19}$ Bambang Sugianto, Interview, Sidoarjo 16 July 2019.

20 Gresham M Sykes, Inmates feel five lost Lost of Liberty, Lost of Security, Lost of Authority, Lost of Sexual, Lost of Good Service in Andi Hamzah, Azas-Azas Hukum Pidana (Jakarta: Rineka Cipta, 1994).
} 
serve as the heads of the household and are responsible for the welfare and security of the family (hifdz al-usrah). ${ }^{21}$

The loneliness in the prison and home longing becomes one of the pulling factors for terrorism convicts to leave their old ideology and begin a new peaceful life while building a family. This occurred in the case of Umar Patek, Toni Saronggalo, and Galih who got the motivation to leave the radical circle through their family's encouragement.

\section{The Quantity of Maslahah}

The policy of granting remission is one way to reduce excess capacity and budget savings in the prisons. Apart of it, it is also a part of social reintegration effort aiming at reuniting inmates with the community while reducing the negative impact of imprisonment on their psychology so that they can reintegrate more easily with the society.

Additionally, granting remission for terrorism convicts providing the condition on their willingness to become justice collaborators is a form of maslahah 'ammah (public advantages). This is mainly because the disclosure of terrorism network will make it easier for the Police and Counterterrorism Special Detachment (Densus 88; Datasemen Khusus) to uncover and even prevent any action plans or amaliyah that endanger the wider community.

When the convicts can well cooperate with the Police or BNPT, existing terrorism network will be weaker because it implies disintegration of the radical group members. Moreover, the absence of support from networks outside the prisons and claims on infidelity for those who participate in deradicalization program will further strengthen the convicts' willingness to return to the unity of the Republic of Indonesia. This, for instance, occurred at the case of Umar Patek and Ali Fauzi. ${ }^{22}$

\section{The Accuracy of Maslahah}

\footnotetext{
21 Jasser Audah, Maqasid Al-Shariah as Philosophy of Islamic Law: A Systems Approach. (London: International Institute of Islamic Thought, 2008).

22 Ali Fauzi, Interview and Discussion, with Religius Rehabilitation Group Singapura, Surabaya 9 November 2019.
} 
The fact on terrorism convicts in Class I Prisons Surabaya and other prisons raises questions about the effectiveness of deradicalization programs and remission grant for terrorism convicts in Indonesia. This is mainly because good behavior in prisons does not always guarantee that the convicts have relinquished their radical beliefs. It is still possible to find very good and cooperative behavior in the prison, including participation in some coaching programs, which comes from deception so that after the release, they return to the old network.

However, apart of some allegation (zani) on the problem described above, granting remission is deemed to have many favorable and definite (qot'iy) impacts on the inmates. This is clear both during sentencing period and after reintegrating to the community. Therefore, a campaign to remove remission chance for terrorism inmates is contrary to the concept of correctional system and the criminalization philosophy namely preventive, rehabilitative, and social reintegration. In other words, the policy seems to restore the criminal system in Indonesia into the prison system as before.

The social reintegration approach of correctional services enables terrorism convicts to get services and acceleration on their return to the public life. Among others, this is done through remission mechanisms as it provides certainty of a broader and better opportunity for inmates to return to society. Still, through a legal formal approach which only concerns with the number in the sentencing, systematic community involvement will be out of consideration. In the later case, the handling of a terrorism convicts will be quite challenging to succeed. ${ }^{23}$

The existence of The Peace Circle Foundation (YLP; Yayasan Lingkar Perdamaian) and The Peace Inscription Foundation (YPP; Yayasan Prasasati Perdamaian) with a new vision and mission as a pulling factor for terrorism convicts really matters. They approach and embrace both terrorism convicts and ex-convicts while getting them thinking about religion and the state. Many of the convicts have realized their mistakes and rebuilt a new life afterward, such as Galih, Toni Saronggalo and some ex-convicts of the Bali bombings in

23 N. V. Paranjape, Criminology \& Penology (Uttar Pradesh: Central Law Publications, 2017). 
Tenggulun. They even drove them self to protect Indonesia from any acts of terrorism with counter-narratives of radicalism and regret for things they did at the past. ${ }^{24}$

\section{The Effectiveness of Maslahah}

Remission becomes motivation for inmates to do self-foster considering that it is a part of their rights and coaching facility inseparable from other coaching programs. They believe that if they can perform their obligations very well, they will be entitled to remission as long as the specified requirements have been fulfilled.

On the contrary, retaliation as punishment coming in various forms will not make a person's condition normal anymore because sanctions are only a means to satisfy the presence of suffering. In these conditions, the punishment can vary from an inmate to another. The granting of remission, meanwhile, implies the meaning giving to the suffering itself as well as consequence of a person's change from a criminal to a common part of society.

Changes among terrorism convicts coming from their own awareness will be clear through effective and permanent ideological changes. This initially can stem, for instance, from meeting and feeling compassion with terrorism victims which later become the driving and pushing factor of ideological change from the heart. This kind of situation deserves for concrete appreciation through reduction of sentencing time (remission) to facilitate the repentance of radicalism believers.

\section{The Duration of Maslahah}

The ultimate goal of coaching programs in the prisons is to change the inmates into good people. When an inmate can show the results of behavior change to be fair, he/she is granted for several rights to alleviate the suffering. The sooner any behavior change is clear as a result of coaching, the sooner the suffering ends or reduces. 25

\footnotetext{
24 Ivan Aditya, "Sekelompok Mantan Napiter Dukung Terciptanya Keamanan," accessed September 12, 2019, https:// krjogja.com/;

${ }^{25}$ Mahrus Ali, Dasar-Dasar Hukum Pidana (Jakarta: Sinar Grafika, 2015).
} 
According to inmate integration aspect, the policy on eliminating remission policy for terrorism convicts with a life sentence can be said as inappropriate or not fulfilling the purpose of criminalization itself. Moreover, the correctional system tends to provide impossible protection of life-sentence inmates on the grounds that their life in prison is indefinite. The reduction of criminal term is therefore something that correctional inmates are waiting for because remission is very special and able to accelerate their process for prison-release.

One of the pulling factors for terrorism inmates to participate in deradicalization programs and get remission as the result is the economic incentives in the form of money/capital assistance for those considered to be well behaved while in prison. The capital was once given to Umar Patek who sold goat satay during his imprisonment. Galih and Supyanto in Lamongan Prison also got the same for a handicraft business they managed in the form of paintings, birdcages and fragrant oil as well as Toni Saronggalo with chicken lathe assistance for his business.

The program is managed by the government through cooperation of BNPT, The Police, and several government agencies hoping that terrorism convicts are willing to leave their old groups and start a new life independently after the release. The government claims that the program has been able to help ex-terrorism convicts to integrate back into society, although not all are effective in this way.

Table 2. Tarjih\} Maqhasidi Remission of Terrorism Convicts Application of Tarjih Maqhasidi

\begin{tabular}{|c|c|c|}
\hline & $\begin{array}{l}\text { Maslahah of Remission for } \\
\text { Terrorism Convicts }\end{array}$ & $\begin{array}{l}\text { Mafsadah of Remission for } \\
\text { Terrorism Convicts }\end{array}$ \\
\hline Qualit & $\begin{array}{l}\text { Granting remission to } \\
\text { terrorism convicts is a } \\
\text { deradicalization offer. It can } \\
\text { return them back to families } \\
\text { and this is included in the } \\
\text { protection of life (hifdz al-nafs) } \\
\text { and protection of human rights } \\
\text { (hifdz alhuquq al-nafs insan) in }\end{array}$ & $\begin{array}{l}\text { The remission grant is } \\
\text { contrary to the certainty of } \\
\text { fair law for the victims. } \\
\text { The abolition of remission } \\
\text { will not impact anything on } \\
\text { the community and is not a } \\
\text { part of daruriyat that should } \\
\text { be imposed on terrorism }\end{array}$ \\
\hline
\end{tabular}


daruriyat category. It is convicts. There found other particularly because the rehabilitative policies which abandoned family will be in are better to be desperate need of the figure of implemented, such as the household head (hifdz usra) deradicalization and as a person responsible for the rehabilitation. welfare.

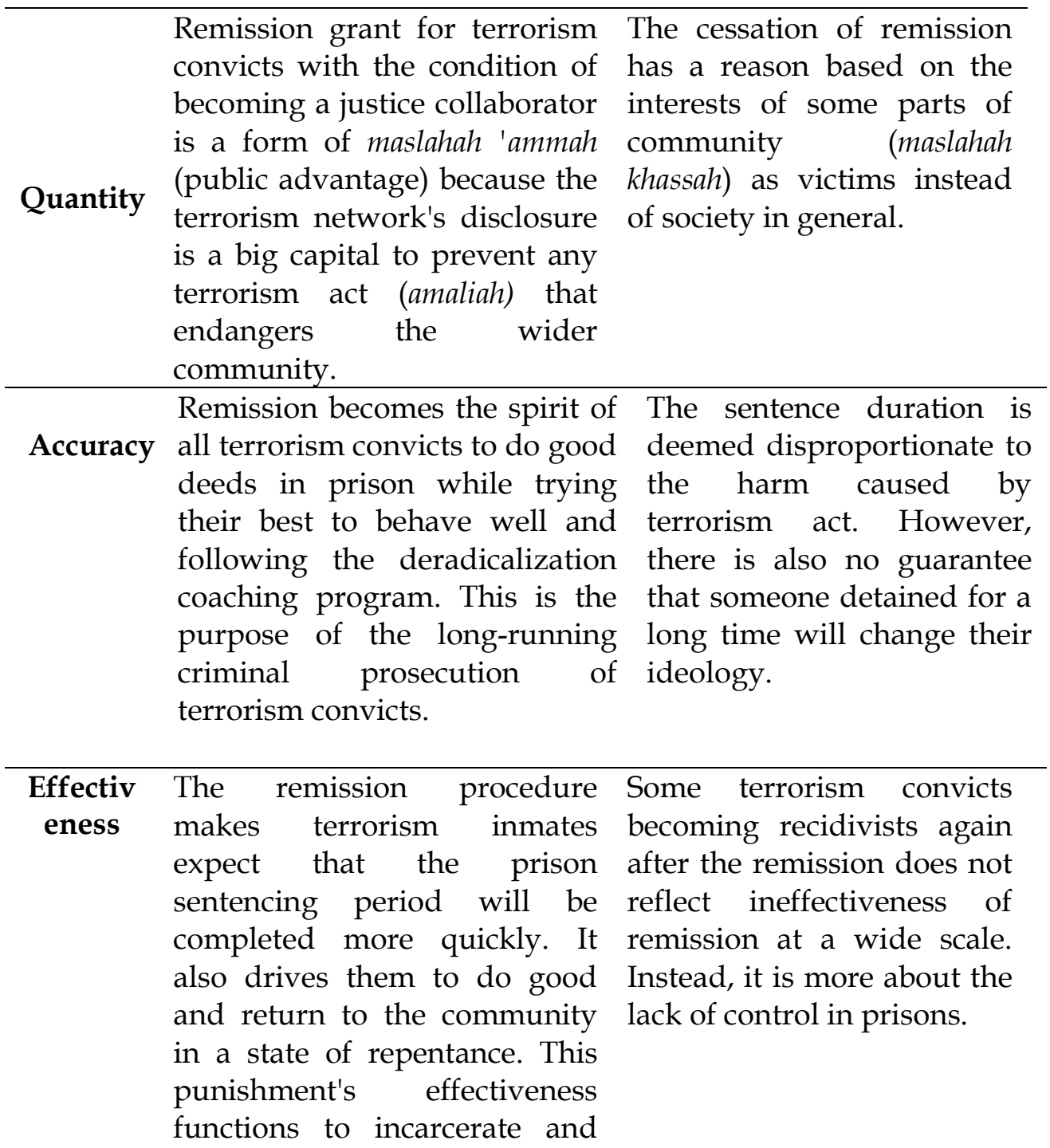


change the inmates for becoming better persons.

The procedure of granting Long-term confinement remission rights can raise without comprehensive Duratio awareness among terrorism deradicalization guidance
n convicts to change, behave has no impact on the well and repent to gain characteristic changes in the freedom faster. terrorism ideology.

\section{Conclusion}

Comparative observation between aspects of maslahah and mafsadah and the consideration of maqhasid shariah in five aspects (quality, quantity, accuracy, effectiveness, and duration) of tarjih maqhasidi show that granting remission for terrorism convicts contain a stronger maslahah (arjah) than abolishing remission for them. Testimonies from sample of terrorism convicts clearly show how they wish for remmision and how it helps them much in building a new life and reintegrating with community both socially and economically.

\section{Bibliography}

Abd Majid Najjar. Maqhasid Al-Shari'ah Bi Ab'ad Jadidah. Beirut: Dar Garib al-Islami, 2008.

Ahmad Al-Raysuni. Nazhariyyat Al-Taqrib Wa Al-Taghlib Fi Al-Ulum AlIsla>miyyah. Kairo: Dar al-Kalimah, 1997.

Ahmad Imam Mawardi. Fiqh Minoritas. Yogyakarta: LKIS, 2010.

Andi Hamzah. Azas-Azas Hukum Pidana. Jakarta: Rineka Cipta, 1994.

Audah, Jasser. Maqasid Al-Shariah as Philosophy of Islamic Law: A Systems Approach. London: International Institute of Islamic Thought, 2008.

Hearne, Naureen Chowdhury Fink and Ellie B. Beyond Terrorism: Deradicalization and Disengagement from Violent Extremism. New York: International Peace Institute, 2008.

Ivan Aditya. "Sekelompok Mantan Napiter Dukung Terciptanya Keamanan." Accessed September 12, 2019. https://krjogja.com/; 
Jalal al-din 'Abd al-Rahman Ibn Abi Bakar al-Suyuti. Tadrib Al-Rawi Fi Sharh Taqrib Al-Nawawi.Beirut: Dar Ihya al-Sunnah alNabawiyyah, 1979.

Mahrus Ali. Dasar-Dasar Hukum Pidana. Jakarta: Sinar Grafika, 2015.

Muhammad al-Asuri. "al-Tarjih bi al-Maqhasid wa Dhawabituhu wa Atsaruhu Fiqhi.” Universitas al-Haj Li Hadar Jazair, 2008.

Muhammad Sa'id Ramadan al-Buti. Dhawabit Al-Maslahah Fi AlShariah Al-Islamiyyah. Beirut: Mu'assasah al-Risalah, 2000.

Paranjape, N. V. Criminology \& Penology. Uttar Pradesh: Central Law Publications, 2017.

Roeslan Saleh and A. Josias Simons R. Budaya Penjara. Bandung: Karya Putra Darwati, 2010.

Widja Priyatno. Sistem Pelaksanaan Pidana Penjara di Indonesia. Bandung: Refika Aditama, 2009.

Sukir, Guidance correctional district Minister of Law and Human Rights (Menkumham) East Java, Interview, Surabaya,

Ali Fauzi, Interview with Religius Rehabilitation Group Singapura, Surabaya 